Urban Agriculture and City Sustainability II 123

\title{
"WHAT'S THE CARBON CONTENT OF YOUR FOOD?": DEVELOPMENT OF AN INTERACTIVE ONLINE FOODPRINT SIMULATOR
}

\author{
KHADIJA BENIS ${ }^{1}$, WALEED ALHAYAZA ${ }^{2}$, ADNAN ALSAATI $^{2} \&$ CHRISTOPH REINHART $^{1}$ \\ ${ }^{1}$ Department of Architecture, Massachusetts Institute of Technology, USA \\ ${ }^{2}$ King Abdulaziz City for Science and Technology, Saudi Arabia
}

\begin{abstract}
As part of their sustainability agendas, cities are promoting urban food production as a means to reduce the demand for agricultural land elsewhere and shorten food miles. However, from an environmental sustainability standpoint, some assessments have shown that increasing self-sufficiency through local production for certain crops is not necessarily more sustainable than the current practice of importing them. Therefore, in addition to quantifying the potential for food self-sufficiency of cities through urban agriculture, there is a need to assess whether such scenarios are indeed more resource efficient than existing supply chains. For that purpose, a fundamental step in the sustainability assessment of alternative local food supply practices is the assessment of existing supply chains, to be used as baseline scenarios of the analysis. In our previous work, we referred to these baseline scenarios as "Urban Foodprints" (UF), a concept that expresses resource consumption and environmental impacts associated with the urban food system, from agricultural production to distribution and consumption. The very first step in building the UF of a given city is collecting information on its actual food demand, which is oftentimes a challenging task due to the scarcity of reliable data sources on food consumption. To fill this gap, this paper presents the development of an online food intake survey that collects a detailed snapshot of the self-reported dietary habits of respondents and probes to what extent their consumption choices are guided by sustainability concerns. By providing respondents with an individualized carbon content analysis of their food intake upon survey completion, this study further aims to raise awareness on the environmental impacts of our food choices as well as which food choices are most impactful. Keywords: survey, food consumption, food system, environmental impacts, urban foodprint.
\end{abstract}

\section{INTRODUCTION}

According to the Intergovernmental Panel on Climate Change (IPCC), the food system as a whole - growing, harvesting, processing, packaging, transporting, marketing, consumption and disposal of food and food-related items - contributes to approximately $26 \%$ of global anthropogenic greenhouse gas (GHG) emissions. This number not only accounts for land use change (i.e., deforestation and peatland degradation), but also for "outside farm gate" emissions from energy, transport and industry sectors for food production (see Fig. 1). In fact, the food system's share of anthropogenic GHG emissions is nearly twice that of the entire transportation sector (14\%) including air travel. With raising societal awareness related to sustainable living, the environmental footprint of the food sector has been under increasing scrutiny by the scientific community over the past decade. The method of choice to study the underlying processes is life cycle assessment [1]. The major portion of emissions $(82 \%)$ stems from agricultural production (i.e., emissions of nitrous oxide resulting from the use of fertilizers; emissions of methane from livestock) and from the loss of carbon sinks as the expansion of agricultural land for crop cultivation and grazing of livestock is propelling deforestation. Outside the farm gate, pre- and post-production sectors represent $18 \%$ of food system emissions. All these numbers show how mitigating emissions from the global food system could have a major impact in the fight against climate change. However, trends in the sector are currently moving in the opposite direction and GHG emissions are actually 
projected to increase, driven by population and income growth and changes in consumption patterns [2].

As part of their sustainability agendas, some cities are promoting urban food production as a means to reduce the demand for agricultural land elsewhere and shorten food miles [4]. However, from an environmental sustainability standpoint, some assessments have shown that increasing self-sufficiency through local production for some crops is not always more sustainable than current practice. For example, a study in the UK showed that producing greenhouse strawberries in London may have a higher carbon footprint than importing Spanish greenhouse strawberries [5]. Therefore, in addition to quantifying the potential for food self-sufficiency of cities through urban cultivation, there is a crucial need to assess the extent to which such scenarios are more resource efficient than existing supply chains. For that purpose, a fundamental step in the sustainability assessment of alternative local food supply practices is the assessment of existing supply chains, to be used as baseline scenarios of the analysis. In our previous work, we referred to these baseline scenarios as "Urban Foodprints" (UF), a concept that expresses resource consumption and environmental impacts associated with the urban food system, from agricultural production to distribution and consumption [6]. The very first step in building the Urban Foodprint of a given city is collecting information on its actual food demand, which is oftentimes a challenging task due to the scarcity of reliable data sources on food consumption.

In our previous studies, we have been using the Food Balance Sheets (FBS) of the United Nations' Food and Agriculture Organization (FAO) as a proxy for food consumption. Online FBS datasets are gathered by FAO every year for 185 nations for about 100 food commodity groups that are supplied for human consumption. Gross national food supply in a given reference period of a country is calculated from the total quantity of food produced plus the total quantity imported, adjusted for changes at national food stock levels and exports. Net food availability is calculated by subtracting the amounts used for animal feed, seeds, industrial or other purposes and losses in the supply chain (see eqn (1) below). This net value is then divided by the country's population estimate to obtain a final figure describing the availability of food commodities, expressed as kilograms per capita per year. This per capita information can also be linked to food composition data and presented as per capita energy intake (kilocalories per day), protein intake (grams per day) and fat intake (grams per day) [7].

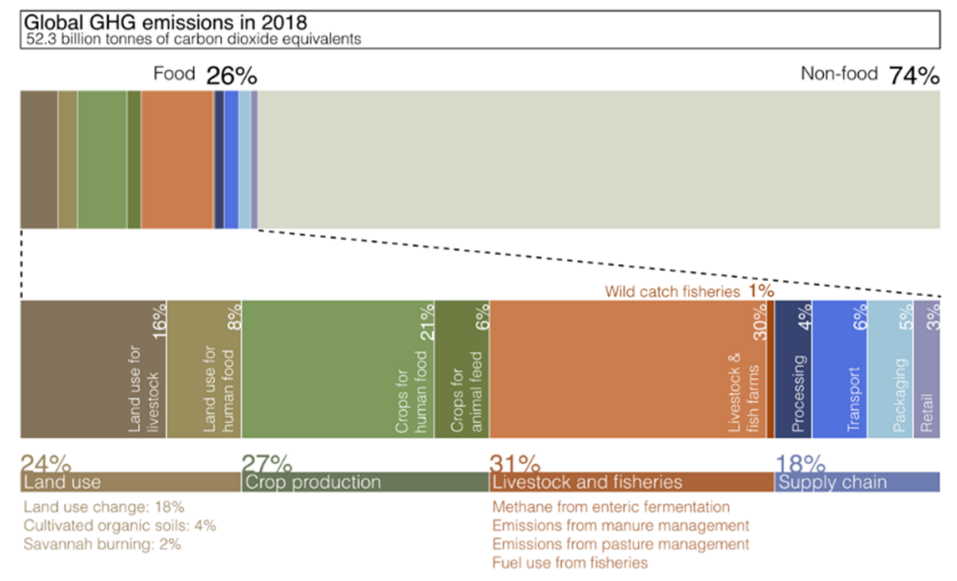

Figure 1: Global GHG emissions versus food system GHG emissions [3]. 


$$
\mathrm{NFS}_{\text {COUNTRY }}=\mathrm{S}_{S T}+\left(F_{D}+F_{I}\right)-\left(F_{E}+S+A F+W+O_{N F U}\right)-S_{E N D},
$$

where: NFS $\mathrm{SOUNTRY}_{\text {is }}$ the net national food supply in a given reference period of a country; $\mathrm{S}_{\mathrm{ST}}$ are the starting food stocks; $\mathrm{F}_{\mathrm{D}}$ is the quantity of food produced domestically; $\mathrm{F}_{\mathrm{I}}$ is the quantity of food imported; $F_{E}$ is the quantity of food exported; $S$ is seed; $A F$ is animal feed; $\mathrm{W}$ is waste (at farm gate); $\mathrm{O}_{\mathrm{NFU}}$ are other non-food uses; $\mathrm{S}_{\mathrm{END}}$ are the ending stocks.

The FAO FBS are generally utilized in research to screen worldwide dietary habits, trends in national food availability, and the capability of a country's supply to meet nutritional needs. However, using these datasets as a proxy for food consumption has some limitations, not only because estimates are based on country statistics which themselves may be subject to methodological errors, but also because domestic and retail food waste are not accounted for. Moving forward, in order to improve the accuracy of our data, this manuscript presents results from an online survey on dietary habits of participants. It is organized as follows: Section 2 synthesizes the existing methods for surveying food intakes and identifies research gaps. Section 3 describes the methodology underlying our survey, followed by the discussion of preliminary results in section 4, and expected outcomes in Section 5.

\section{METHODS FOR SURVEYING INDIVIDUAL FOOD INTAKE}

Conventional approaches for direct data collection of dietary patterns of individuals can be divided into two categories, retrospective and prospective tools. While the former measures past food intake via self- or interviewer-administered recall questionnaires, the latter records food intake at the time of consumption. Table 1 organizes the existing methods following this distinction reviewing in turn both methods' respective descriptions, administration modes, time frames, and limitations as acknowledged in the literature [7].

Bias and misreporting are common issues to all these approaches, at varying degrees. For instance, retrospective methods heavily rely on the respondents' memory and can therefore not only lead to errors when reporting on frequency and portion size estimation, but respondents may also be selective with the foods they choose to report during the recall. On the other hand, prospective methods are burdensome to respondents as they involve documenting (and sometimes weighing) every food and beverage consumed at each meal during a predefined period of time, and therefore may either interfere with respondents' normal eating habits or lead to a decreasing reliability of records over time as food intakes can be missed or less accurately recorded. Furthermore, as both recall- and record-based approaches require multiple days of data collection to adequately represent the habitual food intake of individuals, all these conventional approaches tend to be time-intensive for both respondents and researchers. Consequently, for the latter, all of these methods are labourintensive (and therefore cost-intensive), either requiring well-trained interviewers or involving great amounts of time spent on data entry and food matching with food composition data.

Faced with all these limitations of conventional methods, researchers in the food and nutrition field are more and more looking into integrating innovative technologies to improve dietary assessment (see Table 2) [7].

These new methods seek to replace pen and paper approaches by relying on the use of technologies such as mobile phones or interactive computer software, to reduce memory bias and gather more reliable information. Compared with conventional dietary assessment methods, such approaches reduce the cost of data collection and processing, as they allow researchers to automatically process the collected information and get real-time feedback. 
Table 1: Conventional food intake survey methods.

\begin{tabular}{|c|c|c|c|c|c|c|}
\hline \multirow[b]{2}{*}{ Method } & \multicolumn{3}{|c|}{ 1.1. Retrospective methods } & \multicolumn{3}{|c|}{ 1.2. Prospective methods } \\
\hline & $\begin{array}{l}\text { 1.1.1. } \\
\text { Dietary } \\
\text { history }\end{array}$ & $\begin{array}{l}\text { 1.1.2. Food } \\
\text { Frequency } \\
\text { Questionnair } \\
\text { e (FFQ) }\end{array}$ & $\begin{array}{l}\text { 1.1.3. 24- } \\
\text { hour recall }\end{array}$ & $\begin{array}{l}\text { 1.2.1. } \\
\text { Estimated } \\
\text { food records }\end{array}$ & $\begin{array}{l}\text { 1.2.2. } \\
\text { Weighed } \\
\text { food } \\
\text { records }\end{array}$ & $\begin{array}{l}\text { 1.2.3. } \\
\text { Duplicate } \\
\text { meal method }\end{array}$ \\
\hline Description & $\begin{array}{l}\text { Describe } \\
\text { annual food } \\
\text { intake and } \\
\text { its variation } \\
\text { over a long } \\
\text { period of } \\
\text { time (6 } \\
\text { months-1 } \\
\text { year): (1) } \\
\text { interview; } \\
\text { (2) food list; } \\
\text { (3) 3-day } \\
\text { record with } \\
\text { portion size } \\
\text { estimates as } \\
\text { cross- } \\
\text { checks }\end{array}$ & $\begin{array}{l}\text { Assess the } \\
\text { frequency } \\
\text { with which } \\
\text { foods and/or } \\
\text { food groups } \\
\text { are eaten } \\
\text { over a certain } \\
\text { period. } \\
\text { Questionnair } \\
\text { e includes a } \\
\text { food list and } \\
\text { a frequency } \\
\text { category } \\
\text { section }\end{array}$ & $\begin{array}{l}\text { Respondent } \\
\text { s are asked, } \\
\text { by a trained } \\
\text { nutritionist } \\
\text { or dietitian, } \\
\text { to recall and } \\
\text { report all } \\
\text { food and } \\
\text { beverages } \\
\text { consumed } \\
\text { over the } \\
\text { past } 24 \\
\text { hours }\end{array}$ & $\begin{array}{l}\text { Respondent } \\
\text { s are } \\
\text { instructed to } \\
\text { document } \\
\text { all food and } \\
\text { beverages } \\
\text { consumed } \\
\text { during a } \\
\text { predefined } \\
\text { period (e.g., } \\
1 \text { to } 7 \text { days) }\end{array}$ & $\begin{array}{l}\text { Same } \\
\text { method as } \\
\text { estimated } \\
\text { food } \\
\text { records, + } \\
\text { respondents } \\
\text { are asked to } \\
\text { weigh using } \\
\text { weighing } \\
\text { scales }\end{array}$ & $\begin{array}{l}\text { Respondents } \\
\text { set aside } \\
\text { duplicate } \\
\text { portions of } \\
\text { all foods } \\
\text { consumed, } \\
\text { weighed and } \\
\text { sent to a } \\
\text { laboratory } \\
\text { for chemical } \\
\text { analysis to } \\
\text { determine } \\
\text { nutrient } \\
\text { content }\end{array}$ \\
\hline $\begin{array}{l}\text { Administratio } \\
\mathrm{n}\end{array}$ & $\begin{array}{l}\text { Self- or } \\
\text { interviewer- } \\
\text { administere } \\
\text { d }\end{array}$ & $\begin{array}{l}\text { Self- or } \\
\text { interviewer- } \\
\text { administered }\end{array}$ & $\begin{array}{l}\text { Interviewer- } \\
\text { administere } \\
\text { d }\end{array}$ & $\begin{array}{l}\text { Self- } \\
\text { administere } \\
\text { d }\end{array}$ & $\begin{array}{l}\text { Self- } \\
\text { administere } \\
\text { d }\end{array}$ & $\begin{array}{l}\text { Self- } \\
\text { administered }\end{array}$ \\
\hline Time frame & $\begin{array}{l}\text { Multi-day } \\
\text { recall }\end{array}$ & $\begin{array}{l}\text { Daily, } \\
\text { weekly or } \\
\text { monthly }\end{array}$ & $\begin{array}{l}\text { Multi-day } \\
\text { recall }\end{array}$ & $\begin{array}{l}\text { Multi-day } \\
\text { record }\end{array}$ & $\begin{array}{l}\text { Multi-day } \\
\text { record }\end{array}$ & $\begin{array}{l}\text { Multi-day } \\
\text { record }\end{array}$ \\
\hline $\begin{array}{l}\text { Relies on } \\
\text { respondents' } \\
\text { memory }\end{array}$ & Yes & Yes & Yes & & & \\
\hline $\begin{array}{l}\text { May interfere } \\
\text { with normal } \\
\text { eating habits }\end{array}$ & & & & Yes & Yes & Yes \\
\hline $\begin{array}{l}\text { Time- } \\
\text { intensive } \\
\text { (respondents) }\end{array}$ & + & + & + & ++ & ++ & +++ \\
\hline $\begin{array}{l}\text { Time- } \\
\text { intensive } \\
\text { (researchers) }\end{array}$ & ++ & ++ & +++ & ++ & ++ & +++ \\
\hline $\begin{array}{l}\text { Costly for } \\
\text { respondents }\end{array}$ & & & & & & +++ \\
\hline $\begin{array}{l}\text { Costly for } \\
\text { researchers }\end{array}$ & ++ & ++ & +++ & ++ & ++ & +++ \\
\hline
\end{tabular}

"+" is lowly; "++" is moderately; and "+++" is highly. 
Table 2: Innovative food intake survey methods.

\begin{tabular}{|l|l|l|l|l|l|}
\hline & \multicolumn{5}{|c|}{ 2. Innovative methods } \\
\hline Method & $\begin{array}{l}\text { 2.1. Personal } \\
\text { Digital } \\
\text { Assistant } \\
\text { (PDA) }\end{array}$ & $\begin{array}{l}\text { 2.2. Image- } \\
\text { assisted } \\
\text { methods (i.e., } \\
\text { digital } \\
\text { photographs) }\end{array}$ & $\begin{array}{l}\text { 2.3. Image- } \\
\text { assisted } \\
\text { methods (i.e., } \\
\text { mobile-based } \\
\text { technologies) }\end{array}$ & $\begin{array}{l}\text { 2.4. } \\
\text { Interactive } \\
\text { computer and } \\
\text { web-based } \\
\text { technologies }\end{array}$ & $\begin{array}{l}\text { 2.5. Scan- } \\
\text { and sensor- } \\
\text { based } \\
\text { technologies }\end{array}$ \\
\hline Description & $\begin{array}{l}\text { Specially- } \\
\text { designed } \\
\text { dietary } \\
\text { software } \\
\text { program used } \\
\text { to register } \\
\text { dietary intake. } \\
\text { Participants } \\
\text { receive training } \\
\text { on how to use } \\
\text { the device and } \\
\text { record their } \\
\text { food intake by } \\
\text { selecting food } \\
\text { items from a } \\
\text { list }\end{array}$ & $\begin{array}{l}\text { Method that } \\
\text { uses images } \\
\text { (i.e. } \\
\text { photographs, } \\
\text { videos) of } \\
\text { food collected } \\
\text { during eating } \\
\text { episodes to } \\
\text { enhance } \\
\text { accuracy and } \\
\text { reduce } \\
\text { respondent } \\
\text { burden and } \\
\text { memory bias }\end{array}$ & $\begin{array}{l}\text { Allow users } \\
\text { to shoot } \\
\text { images or } \\
\text { make voice } \\
\text { records using } \\
\text { a smartphone } \\
\text { or tablet }\end{array}$ & $\begin{array}{l}\text { Involve the } \\
\text { use of } \\
\text { interactive } \\
\text { dietary } \\
\text { assessment } \\
\text { programs } \\
\text { installed on a } \\
\text { computer; the } \\
\text { "web-based" } \\
\text { moniker } \\
\text { refers to these } \\
\text { devices being } \\
\text { connected to } \\
\text { the internet }\end{array}$ & $\begin{array}{l}\text { Participants } \\
\text { scan the } \\
\text { barcodes of } \\
\text { purchased } \\
\text { food items; } \\
\text { sensor-based } \\
\text { to be bigned } \\
\text { memory- } \\
\text { independent } \\
\text { and almost } \\
\text { passive for } \\
\text { participants }\end{array}$ \\
& & & \\
\end{tabular}

\section{THE FOODPRINT SIMULATOR - MATERIALS AND METHODS}

Whereas conventional pen and paper methods (Table 1) are usually burdensome and costly to both users and researchers (and potentially less accurate), technology-based approaches (Table 2) are increasingly being used to monitor food intake. However, even within this group of approaches, choosing a survey method depends on the objective of the particular study that is being undertaken. This section describes the goals and methodology underlying the development of the FOODprint Simulator, as well as the data sources used for that purpose.

\subsection{Objective}

As mentioned in Section 1, the goals of this study are two-fold: (1) being able to define accurate baseline scenarios of food consumption based on actual feedback from consumers; and (2) raising awareness on the environmental impacts of food. For this purpose, our research requirements not only imply reaching a wide audience in a cost-effective manner, but also ensuring an adequate level of accuracy. We therefore chose to develop the FOODprint Simulator within the methodological framework of the "Innovative methods" group (see Fig. 2), as a survey that consists of a web-based, self-administered questionnaire, with a core part inviting respondents to build typical meals that represent their daily food consumption habits. Compared to other personal food trackers available on the market, the novelty of this tool lies in providing an additional set of information to the users besides nutritional data, i.e., the carbon content of their diets. 


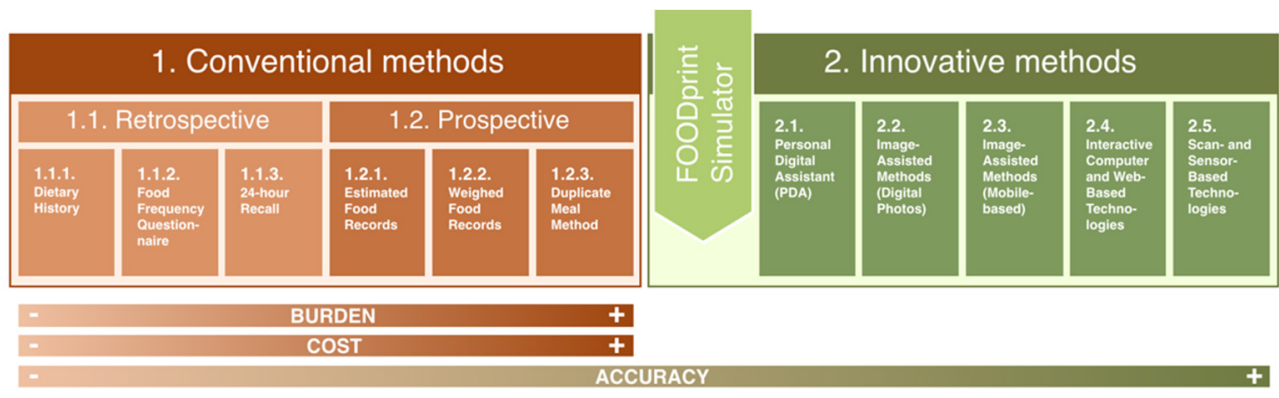

Figure 2: Methodological framework of the FOODprint Simulator.

\subsection{Questionnaire structure}

The FOODprint Simulator questionnaire contains three Sections, followed by a final page displaying the results. Section 1, entitled "About you," collects general demographic information, such as gender, age, place of residence, level of education, and general activity level. From gender, age and activity level data, a "normal" daily calorie intake is generated to help participants gauge whether their entries are plausible. Section 2, entitled "What's on your plate?" is the core of the survey, where respondents are invited to build as many typical meals and they wish, in a way that consistently represents their food intake. To do so, they can select food and beverage items from a list (that also provides pictures of serving sizes for reference) and drop them into a food tray. To adjust portion sizes of food, they can add more servings; drink sizes can be adjusted as well. Throughout the whole process of composing meals, respondents are able to check their average calorie count as well as their carbon emissions. Section 3, entitled "What are your shopping preferences", gathers some additional information on the respondents' grocery shopping habits, containing questions about the preferences that guide their choice of products when purchasing food. This section will inform us on the potential links of sustainability concerns with food consumption habits, and the willingness of consumers to pay a premium for sustainably sourced products. Finally, upon completion of the survey, respondents get to visualize the total carbon content of their food, as well as its breakdown into the main six food groups of the FAO classification. To better understand their results, they can compare them to the average carbon footprint of food supply in their country and worldwide (see Fig. 3).

\subsection{Underlying calculations and datasets}

The conception of Section 2, "What's on your plate?," involved the development of an underlying database and calculation system that provides instantaneous feedback to the user, as he is defining his meals. Efforts were made - on the whole survey in general and on this section in particular - to build an attractive and intuitive interface that would arouse the respondents' curiosity and make them want to dedicate some time and attention to building typical meals and exploring the associated nutritional and environmental information provided instantaneously by the tool. Behind this interface, our database uses the FAO taxonomy, which classifies food into six categories (meat; dairy and eggs; grain; produce; sugar and fat; and other), subdivided into 20 sub-groups (see Fig. 4).

Each time the user drops a food or beverage item into his tray, carbon and calorie contents are calculated within the database, according to the composition of the food item and using 
reference values of calorie content and carbon intensity, multiplied by the selected portion size. Average carbon intensities of all food items were sourced from various Life Cycle Assessment (LCA) studies.

Additionally, to enable the user to compare his final FOODprint to the average carbon footprint of food supply in his country and worldwide, the database contains country-specific data, calculated using food and calorie supply data from the FAOSTAT database.

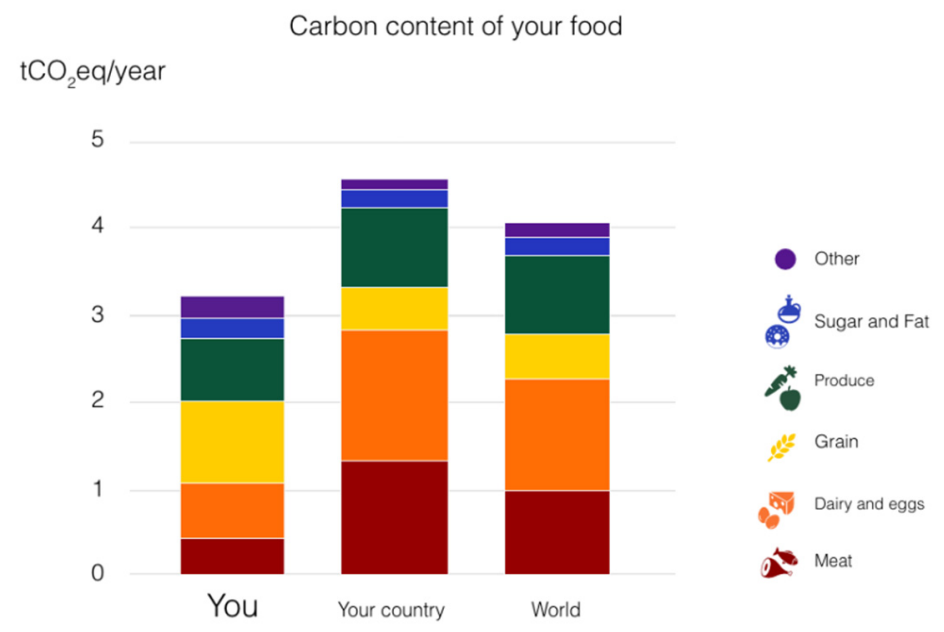

Figure 3: Final results displayed at the end of the survey.

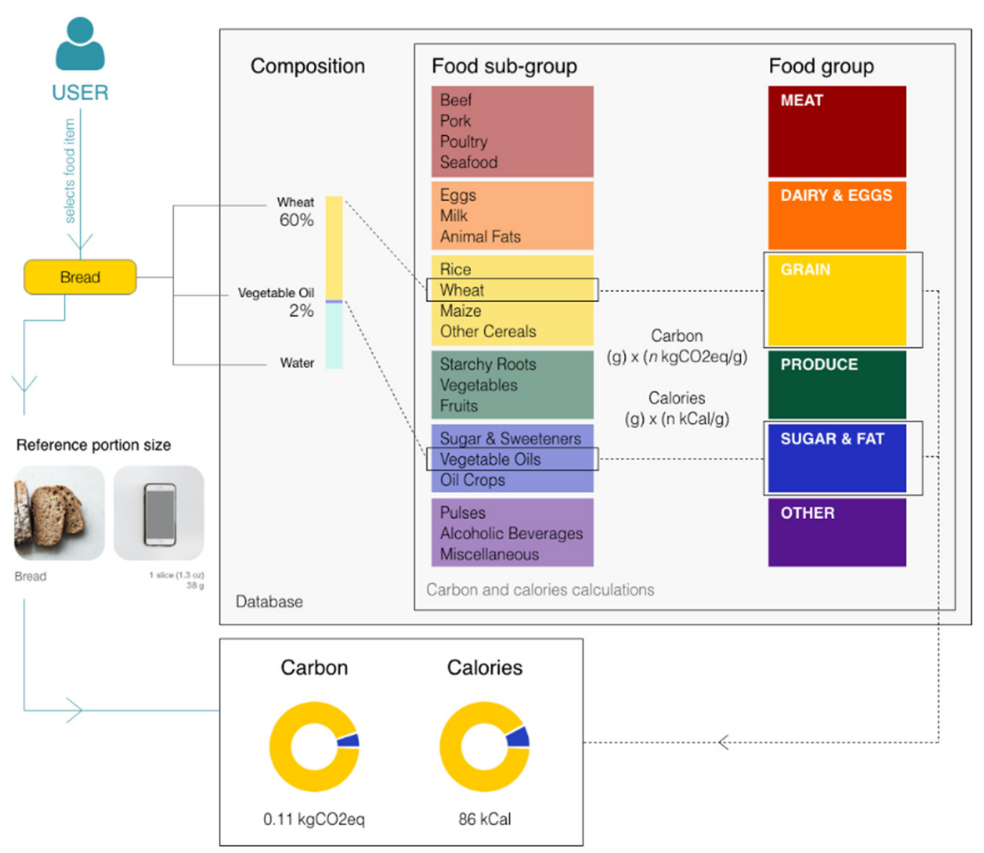

Figure 4: Workflow for an example food item. 


\section{APPLICATION OF THE SURVEY AND PRELIMINARY RESULTS}

The FOODprint Simulator was published online in March 2020. Its cover page provided a short description of the objective of the study. The confidentiality of replies was highlighted, and an average completion time was suggested. The survey was disseminated through several social media platforms. It was completed by 262 respondents between March and May. This section presents some preliminary results from this first deployment phase.

\subsection{Distribution strategy}

As of $2019,59 \%$ of the world's population uses the internet, representing a large opportunity for the emerging online data collection method. In comparison to conventional survey techniques, online surveys are a cost- and time-efficient way of collecting data, allowing researchers to get feedback faster and from a broader audience. At the same time, data processing and analysis can be done in real-time as responses are being collected, and anonymity can encourage respondents to provide more honest answers. Furthermore, $80 \%$ of internet users are also active social media users, hence our distribution strategy, not only via emails through our mailing lists, but also through the main social media platforms (e.g., Twitter, Instagram, Facebook).

\subsection{Preliminary results}

\subsubsection{Demographic characterization}

The respondents were from 17 different countries, with a predominance of residents of Saudi Arabia (54\%) and the United States (32\%) - the two pilot countries where most of our dissemination efforts were focused. Young and middle-aged were the prevalent age groups, with $31 \%$ of the respondents belonging to the $25-34$ group; $30 \%$ to the $35-49$ group; and $26 \%$ to the 19-24 group. Almost two-thirds of the respondents were female (63\%); $88 \%$ of the respondents have a higher education degree. Finally, most of the respondents reported low to moderate activity levels $-44 \%$ exercised once a week or less; $42 \%$ exercised 1 to 3 times a week; and only 14\% exercised at least 5 times a week.

\subsubsection{Carbon FOODprint}

The average carbon content of the respondents' diets, by age group, are shown in Fig. 5, with overall FOODprints ranging between 2.1 and $2.9 \mathrm{tCO}_{2} \mathrm{eq} /$ year. When broken down by food items, dairy, meat and eggs dominate across all age groups, accounting for 54 to $66 \%$ of carbon FOODprints.

At the same time, meat-related carbon emissions decreased among older populations, accompanied by a slight increase in produce-related emissions. Such a trend might reflect healthier dietary habits related to ageing.

\subsubsection{Sustainability awareness}

The third section of the survey allows decision-makers to gauge the potential links of sustainability concerns with food consumption habits, and the willingness of consumers to pay a premium for sustainably sourced products. Across all age groups, respondents showed a preference for local, organic, and low-carbon foods, although some of them changed their answers when asked about their willingness to pay a 50\% premium for these products (see Fig. 6). 


\section{$\mathrm{tCO}_{2}$ eq/year}

3

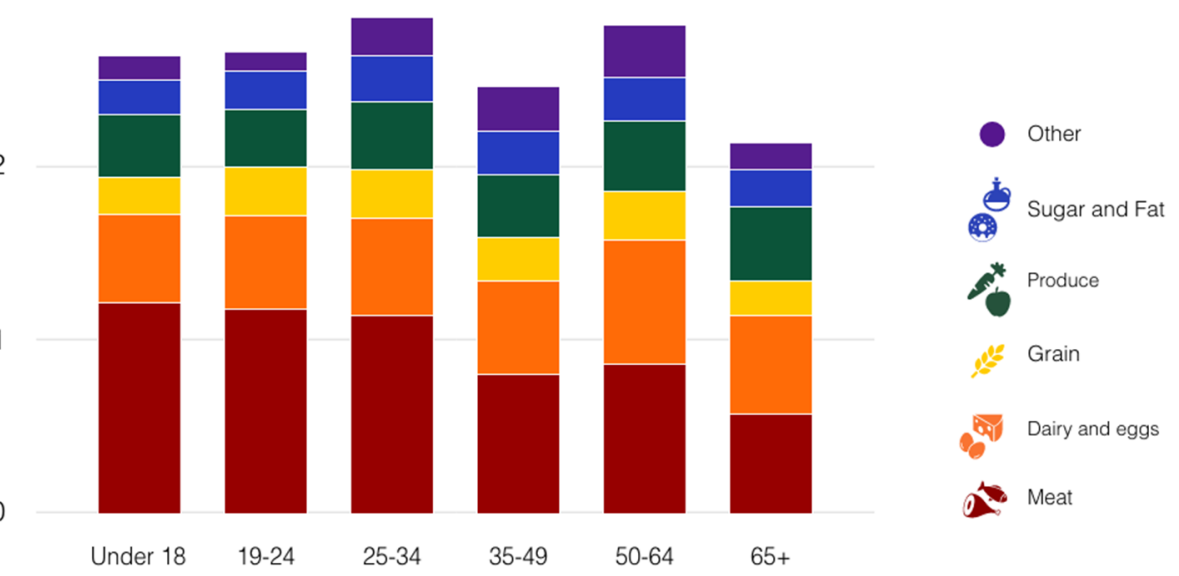

Figure 5: Carbon content of respondents' diets, by age group.
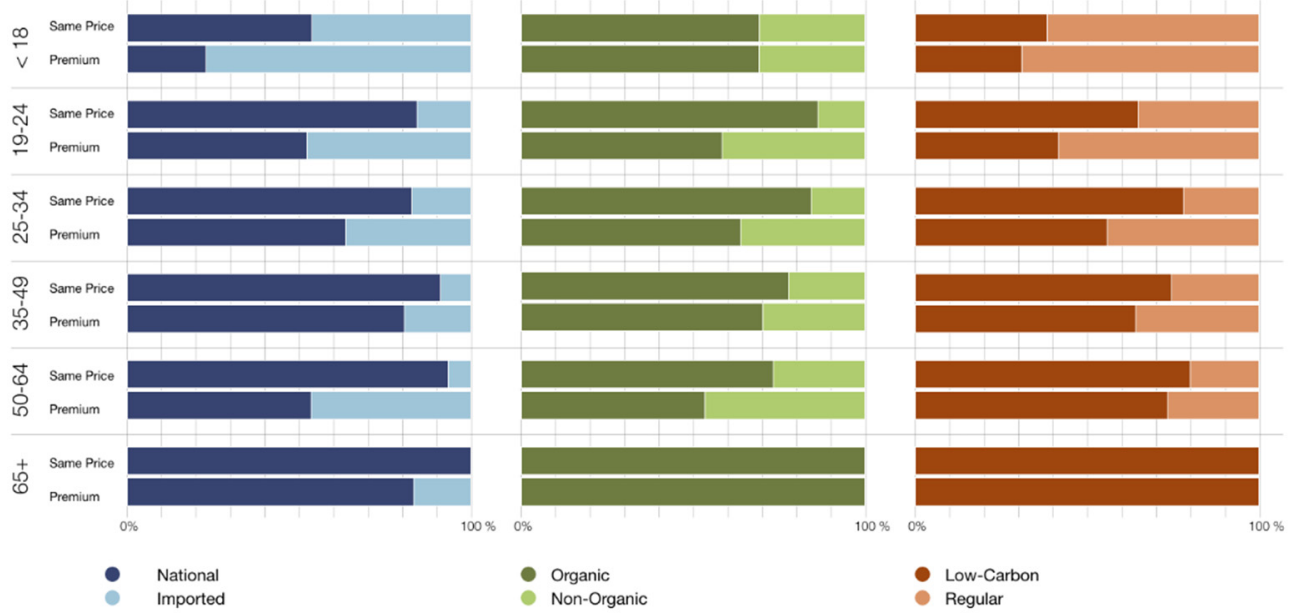

Figure 6: Shopping preferences, by age group.

\section{NEXT STEPS}

Carbon accounting is largely used, not only as a sustainability assessment tool of products and companies, but also as a powerful instrument to raise awareness about climate change. Given that food-related carbon emissions represent one quarter of total anthropogenic emissions, it is crucial to estimate accurately these emissions in order to define paths of mitigation. In that sense, the FOODprint Simulator is a powerful tool both for decisionmakers and for sustainability consultants, willing to quantitatively assess the impacts of local food production in a given neighbourhood or city, against current scenarios. 
Recently, during a major event of the Expo 2015, the city of Milan promoted an international protocol, engaging the largest number of world cities for the development of food systems, based on the principles of sustainability. The Milan Urban Food Policy Pact was signed by more than 200 cities all over the world. The simulator can help collecting useful information on dietary patterns and food sustainability awareness, for policy makers to understand better the demand of their residents and be able to tailor policies accordingly.

The preliminary results presented here were aimed at troubleshooting the survey and improving it through the feedback obtained from the first set of respondents. We will further work together with institutional, academic and corporate study groups, where the survey will be administered in a more focused manner, in sessions where a trained person or educator will guide respondents through the process of defining their food intake. Through all these channels, the survey will be deployed and available for at least one full year

\section{ACKNOWLEDGEMENTS}

Generous support for this work has been provided by the King Abdulaziz City for Science and Technology (KACST) as part of the research under the Center for Complex Engineering Systems (CCES) at MIT and KACST through the Urban Water, Energy and Food project.

\section{REFERENCES}

[1] Benis, K. \& Ferrão, P., Potential mitigation of the environmental impacts of food systems through urban and peri-urban agriculture (UPA): A life cycle assessment approach. Journal of Cleaner Production, 140, pp. 784-795, 2017.

DOI: 10.1016/j.jclepro.2016.05.176.

[2] Intergovernmental Panel on Climate Change, Climate change and land: An IPCC special report on climate change, desertification, land degradation, sustainable land management, food security, and greenhouse gas fluxes in terrestrial ecosystems, 2019.

[3] Poore, J. \& Nemecek, T., Reducing food's environmental impacts through producers and consumers. Science, 360(6392), pp. 987-992, 2018. DOI: 10.1126/science.aaq0216.

[4] Baker, L. \& de Zeeuw, H., Urban food policies and programmes: An overview. Cities and Agriculture: Developing Resilient Urban Food Systems, pp. 26-55, 2015.

[5] Kulak, M., Graves, A. \& Chatterton, J., Reducing greenhouse gas emissions with urban agriculture: A life cycle assessment perspective. Landscape and Urban Planning, 111(1), pp. 68-78, 2013. DOI: 10.1016/j.landurbplan.2012.11.007.

[6] Benis, K., Gashgari, R., Alsaati, A. \& Reinhart, C., Urban foodprints (UF): Establishing baseline scenarios for the sustainability assessment of high-yield urban agriculture. International Journal of Design \& Nature and Ecodynamics, 13(4), pp. 349-360, 2018. DOI: 10.2495/DNE-V0-N0-1-12.

[7] FAO, Dietary assessment: A resource guide to method selection and application in low resource settings, Rome, 2018. 